\title{
Labor Market Shocks and Early Social Security Benefit Claiming
}

David Card, Nicole Maestas, and Patrick Purcell

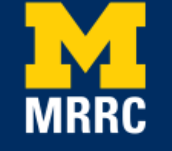

Project \#: UM11-14 


\title{
Labor Market Shocks and Early Social Security Benefit Claiming
}

\author{
David Card \\ University of California-Berkeley \\ Nicole Maestas \\ RAND \\ Patrick Purcell \\ Social Security Administration
}

December 2014

\author{
Michigan Retirement Research Center \\ University of Michigan \\ P.O. Box 1248 \\ Ann Arbor, MI 48104 \\ www.mrrc.isr.umich.edu \\ (734) 615-0422
}

\section{Acknowledgements}

This work was supported by a grant from the Social Security Administration through the Michigan Retirement Research Center (Grant \# 5 RRC08098401-03-00). The findings and conclusions expressed are solely those of the author and do not represent the views of the Social Security Administration, any agency of the Federal government, or the Michigan Retirement Research Center. 


\title{
Labor Market Shocks and Early Social Security Benefit Claiming
}

\begin{abstract}
Many job-losers suffer large and persistent losses in earnings capacity. For displaced workers who are age-eligible, one reaction to these losses is to begin claiming Social Security retirement benefits. We use administrative earnings records from the Social Security Administration's Continuous Work History Sample to study the impacts of labor market shocks among workers in their late 50s and early 60s on Social Security retirement benefit claiming rates. We find that labor market shocks lead to current and future increases in the fraction of insured workers who initiate Social Security benefits at the earliest possible claiming age. Moreover, once they initiate benefits, early claimants continue to have low levels of earnings in all subsequent years.
\end{abstract}

\section{Citation}

David Card, Maestas, Nicole, and Purcell, Patrick. 2014. "Labor Market Shocks and Early Social Security Benefit Claiming." Ann Arbor MI: University of Michigan Retirement Research Center (MRRC) Working Paper, WP 2014-317.

http://www.mrrc.isr.umich.edu/publications/papers/pdf/wp317.pdf

\section{Authors’ Acknowledgements}

We thank Orla Hayden for outstanding programming support. This research was funded by the Social Security Administration (SSA) through the Michigan Retirement Research Center under grant \#UM 11-14. The findings and conclusions expressed are solely those of the authors and do not represent the opinions or policy of SSA, or any agency of the federal government. 
Nearly one out of three Americans claims Social Security retirement benefits at age 62, the earliest possible claiming age. ${ }^{1}$ Although the early claiming rate has trended downward over the past 15 years, it surged by four percentage points during the Great Recession and remains substantial at 31 percent in 2012. Because retirement benefits are actuarially reduced for claimants who initiate benefits prior to their "full retirement age," early claiming does not directly affect the solvency of the Social Security system. However, the lower benefit levels may lead to lower living standards and a higher risk of poverty for early claimants and their families (Gruber and Orzag, 2003). Indeed, the average retirement benefit for early claimants in 2012 was only $\$ 1,148$ per month (Social Security Administration, 2013) - just under the Federal poverty line for a family of two.

One explanation for the early claiming of benefits is diminished labor market opportunities resulting from economic shocks such as job displacement. A large body of work has shown that workers who are displaced from a long-term job suffer persistent losses in potential earnings (e.g., Jacobson, Lalonde, and Sullivan, 1993; Von Wachter, Song, and Manchester, 2009). These losses appear to be particularly large for those who lose a job during a cyclical downturn. Davis and von Wachter (2011), for example, estimate that male workers with significant previous job tenure experience losses of approximately $20 \%$ of their expected future earnings if they are displaced in a recession.

\footnotetext{
${ }^{1}$ Authors' tabulations of new Social Security Retirement benefit claims from Annual Statistical Supplement to the Social Security Bulletin (2013), Table 6.B.5 divided by Census intercensal estimates of U.S. population age 62 by year.
} 
For workers who have reached age 62 , one response to a negative earnings shock is to initiate early Social Security retirement benefits (see e.g., Coile and Levine, 2007). ${ }^{2}$ To illustrate the strength of this response, Figure 1 shows the fraction of people born from 1934 to 1947 who began claiming retirement benefits at age 62, along with the annual unemployment rate in the years they turned 62 . While early claiming rates have generally trended down among later cohorts, this pattern was interrupted by the recession in the early 2000s - which impacted cohorts born in 1939 and 1940 - and particularly by the onset of the Great Recession in 2009 - which led to a sharp rise in early claiming rates by people born in 1947. After accounting for long term trends the correlation between early claiming rates and the unemployment rate at age 62 is a highly significant -0.4.

The simple patterns in Figure 1 may understate the long run effects of a cyclical downturn for two reasons. First, workers who are younger than 62 but experience a negative shock may "bide their time" in part-time and lower-wage jobs until they reach their $62^{\text {nd }}$ birthday and can file for retirement benefits. Thus, a serious recession may end up impacting early claiming rates for several cohorts - not just those who are on the cusp of eligibility for benefits. Second, to the extent that people who have started to claim retirement benefits face disincentives to work because of the Retirement Earnings Test, labor market shocks that push people into early claiming may lead to lower earnings after age 62 , further magnifying the costs of these shocks.

In this paper we use administrative data from the Social Security Administration's Continuous Work History Sample to study the effects of recent and lagged labor market shocks on the rate of initiation of Social Security retirement benefit claims. We also

2 Younger workers with a serious health condition may initiate a disability benefit claim (Black, Kermit and Sanders, 2002; Autor and Duggan, 2003). 
examine the patterns of earnings changes associated with early claiming and provide estimates of the impacts of early claiming on earnings after age 62 . We focus on people who were working at age 57 and not already claiming federal disability benefits by that age, following them over the next 5 to 14 years (depending on their birth cohort). To address concerns about worker mobility in response to negative shocks in their local labor market, we assign each worker their location as of age 57.3

Our analysis points to two main conclusions. First, there is strong evidence that people who experience negative labor market shocks in their late 50s and early 60s are likely to begin claiming Social Security retirement benefits as soon as they can. This is evident both from the downward trend in their earnings prior to age 62 , and from the strong correlation between early claiming and local labor market shocks experienced between ages 57 and 62. Second, once they begin receiving benefits, early claimers have very low earnings (typically less than $\$ 2500$ per year), regardless of how much they were earning in the years prior to claiming. Interestingly, the post-initiation earnings of people who begin claiming benefits at age 62 are not very different from those who begin claiming at ages 63 or 64, while early claimants as a group are substantially different from those who initiate benefits on or after their FRA.

\section{Social Security Retirement Benefits and the Earnings Test}

U.S. workers become fully insured for Social Security retirement benefits once they have earned 40 Social Security work credits. A worker receives one credit for every calendar quarter in which total earned income from Social Security-covered employment is

3 Yagin (2014) shows that mobility responses to local labor market shocks during the 2001-2011 period were relatively small. 
at least $\$ 1,220$ (in 2015). According to the Social Security Administration, about 96 percent of the U.S. workforce is now covered by Social Security. A worker's monthly retirement benefit is based on his or her average indexed monthly earnings (AIME), computed over the highest 35 years of earnings. A worker's Primary Insurance Amount (PIA) is a piecewise linear function of the AIME. In 2015, the PIA is 90 percent of the first $\$ 826$ of the AIME plus 32 percent of the amount between $\$ 826$ and $\$ 4,980$ plus 10 percent of the amount over $\$ 4,980$. The percentages are constant from year to year while the "bend points" in the PIA formula are indexed to annual average wage growth.

The PIA is the benefit payable if a worker initiates retirement benefits at the full retirement age (FRA). If benefits are initiated before the FRA, they are actuarially reduced by 7-8 percent per year, whereas benefits initiated after the FRA are actuarially increased by a similar amount. ${ }^{4}$ For example, an individual with a full retirement age of 66 and who claims retirement benefits at 62 will receive a monthly benefit equal to 70 percent of his or her PIA.

While the earliest benefit claiming age is 62 for all birth cohorts, the full retirement age is following a scheduled increase. Birth cohorts born in or before 1937 had an FRA of 65. The FRA for the 1938 cohort was 65 and 2 months and increased by two months for successive birth years through the 1943 cohort. The FRA is 66 for the cohorts born between 1943 and 1954, and will increase again in two-month increments for the cohorts born between 1955 and 1960. The FRA is 67 for all cohorts born in 1960 or later.

Figure 2 shows trends in benefit initiation by age for members of the 1934 through 1947 birth cohorts in SSA's Continuous Work History Sample who were employed at age

${ }^{4}$ The delayed retirement credit has also followed a scheduled increase, becoming actuarially fair at 8 percent per year for the cohorts born in 1943 and later (from a low of 3.5 percent for the cohorts born before 1927). 
57 (see Section II for detail about these data). The most striking elements of the figure are the linear decline in the fraction initiating benefits at 65 and the coincident increase in the fraction starting benefits at 66 . The shift from age 65 to 66 occurs for the 1938 through 1943 cohorts, which were the first birth cohorts affected by the scheduled increase in the FRA at a rate of two months per year. ${ }^{5}$ The figure also shows the steady decline in the fraction starting benefits at the earliest claiming age. Some of the decline may be attributable to the increasing actuarial penalty for early claiming that accompanied the rise in the FRA, although the figure indicates the decline in claiming at age 62 may have predated the cohorts affected by the change in the FRA.

Since the Social Security program's inception, retirement benefits have been reduced when beneficiaries earn substantial income after initiating benefit payments. Prior to the year 2000, a retirement earnings test applied to all beneficiaries under age 70 . In 2000, Congress removed the earnings test for beneficiaries at or above the full retirement age, but maintained the test for early claimants, presumably as a device to deter early claiming. At present, the benefits of early claimants are reduced by $\$ 1$ for every $\$ 2$ of earnings above the exempt amount $\left(\$ 15,720\right.$ in 2015) until the beneficiary reaches FRA ${ }^{6}$; from that point on, benefits are increased to compensate for the earlier withholding, at the same actuarially fair rate used to adjust benefits for early or delayed claiming. Thus, the earnings test has no effect on the present value of benefits for a beneficiary with average life expectancy; it only affects the timing of benefit payments. That said, until recent years, the fact that earnings test withholdings are later restored in the form of higher benefits was

\footnotetext{
${ }^{5}$ See also Song and Manchester (2007) for a detailed analysis of the effect of the increase in the FRA on the timing of benefit claiming.

${ }^{6}$ In the calendar year of FRA attainment, the exempt amount is substantially higher at $\$ 41,880$ in 2015.
} 
not well publicized, and the research evidence suggests beneficiaries have viewed the earnings test as a tax (Gruber and Orzag, 2003). Finally, while working after early claiming can result in temporarily reduced benefits due to the earnings test, working can also result in increased benefits. The AIME is recomputed annually to account for new earnings and if the new earnings exceed earnings in one of the years included in the AIME calculation, the individual's benefit is increased accordingly.

Viewed as an implicit tax on earnings in a static framework, the earnings test alters a beneficiary's budget constraint in the classic manner of a transfer program. For those whose potential earnings are below the disregard level, economic theory suggests the earnings test has no effect; for those whose potential earnings are between the disregard level and their break-even level of labor supply, there are offsetting substitution and income effects of the benefit offset. For those with potential earnings well above the breakeven level, the earnings test has an income effect. The disregard level has varied substantially across birth cohorts and years, and often unpredictably (see Friedberg and Webb (2009) for a catalog of historical changes).

The literature offers somewhat mixed evidence on the labor supply effects of the earnings test, with the balance of the evidence pointing to a modest labor supply distortion. Friedberg $(1998,2000)$ finds that in the absence of the earnings test employment among 65-year-old men would be 5.3 percent higher. Haider and Loughran (2007) examine the 2000 elimination of the test above the FRA and conclude that about 5 percent of male workers adjust their earnings in response to the earnings test. Song and Manchester (2007) find that the earnings test only affects those with earnings just above the earnings test exempt threshold. Gustman and Steinmeier (2004) use a structural model to predict 
relatively large effects of the elimination of the earnings test, particularly among those with a high discount rate. In contrast, Gruber and Orzag (2003) find little labor supply effect for men and a small effect for women. Friedberg and Webb (2009) revisit the question using panel data and utilizing unexploited variation in the test from numerous changes in the exempt amount over time; they find that employment following the elimination of the earnings test in 2000 increased by about 2 percentage points at ages $66-69$ and 3.5 points at age 65 , and persisted in succeeding years.

A more subtle issue is whether the labor supply behavior of early claimants is affected even once they reach full retirement age and are no longer affected by the test. Gelber, Jones and Sacks (2013) find that Social Security claimants who suppressed their earnings in order to avoid the retirement earnings test were slow to subsequently adjust their earnings when the disregard amount was raised or when the test was eliminated for older claimants in $2000 .{ }^{7}$ They ascribe this finding to the presence of labor market frictions that impeded the adjustment of earnings to policy changes. This and related evidence from the federal disability insurance system suggest that there may be a permanent distortionary effect on earnings of early benefit claimants. ${ }^{8}$

\section{Data and Summary Statistics}

Our primary data source is the Social Security Administration's Continuous Work History Sample (CWHS). The CWHS is a one-percent sample of Social Security Numbers

\footnotetext{
${ }^{7}$ In 2000, Congress repealed the earnings test for claimants who had reached their full retirement age (65 to 67 depending on birth cohort), but left in place the test for early claimants.

${ }^{8}$ Autor, Maestas, Mullen and Strand (2014) find that Social Security Disability Insurance (SSDI) applicants who suppress labor supply in response to strict limits on allowable earnings while their applications are under review have lower subsequent earnings; they attribute this finding to human capital depreciation during the application review period.
} 
issued from 1937 to the present time, and contains longitudinal earnings and employment data, limited demographic data, and the record of benefit receipt. We use data for the period beginning in 1991 and ending in 2009, the latest year of data available at the time of extraction. Th earnings data in the CWHS are derived from SSA's Master Earnings File (MEF), which includes annual earnings in both covered and uncovered employment from Internal Revenue Service (IRS) Form W-2, quarterly earnings records, and annual income tax forms. For 1978 and later years, the CWHS provides total earnings, including earnings in uncovered sectors and earnings over the annual maximum amount subject to Social Security payroll taxes. Earnings in the CWHS are total annual earnings summed over all employers. ${ }^{9}$ The demographic data come from SSA's Numident file and the benefit receipt data come from the Master Beneficiary Record (MBR).

To identify geographic location, we merged our CWHS extract with SSA's Longitudinal Employee-Employer Data (LEED) file. The LEED file is a one-percent sample of SSNs for which wage and salary employment was reported and includes an employer identification number for each employer from which an individual received earnings in a year and the amount of earnings received from each employer. The LEED also includes employer state and county codes. For individuals with earnings from more than one employer in a year, we used the geographic information of the employer at which their annual earnings were highest.

To measure local labor market conditions we use state annual employment counts (aggregated across all ownership sectors) from the Quarterly Census of Employment and

\footnotetext{
${ }^{9} \mathrm{MEF}$ data included only partial coverage of self-employment income through 1992 and full coverage of selfemployment income thereafter. For more information about the CWHS and related files, see Olsen and Hudson (2009) and Panis et al. (2000).
} 
Wages (QCEW) for the period 1990-2009. We use the annual change in the logarithm of total state employment as our primary indicator of the local labor market "shock" experienced by each worker. These data were merged to each CWHS earnings record by state and year, using the location of each person's employer at age 57 as their state.

Our analysis sample consists of all CWHS individuals who reached age 57 in or after 1991, had positive earnings in the year of their $57^{\text {th }}$ birthday, and who reached age 62 or greater by 2009. This consists of the birth cohorts from 1934 to 1947 . We exclude individuals with missing state information at age 57 and those who begin receiving Social Security Disability Insurance benefits by age 57 . Our final analysis sample includes 224,530 individuals.

Table 1 presents summary statistics for our analysis sample as a whole and by early claiming status. In the full sample, 52.5 percent of individuals are male, 83.6 percent are white non-Hispanic, 9.3 percent are Black, and 1.2 percent are Hispanic. The sample composition is similar by claiming age, with only slightly more age- 62 claimants being White, non-Hispanic and slightly fewer being Hispanic. Benefit initiation among the sampled birth cohorts is concentrated at age 62 , with 30.8 percent claiming at the earliest possible age. Another 10 percent claim early at 63 and 4.6 percent claim early at 64 . The percent claiming at some point during their $65^{\text {th }}$ year i 15.2 percent, which would have been claiming at FRA for the 1934-1942 birth cohorts, but early claiming for the cohorts born in 1943 and later who had an FRA of 66. About one-fifth of the sample claimed at age 66, which would have been "late" claiming for the 1934-1942 cohorts but claiming at FRA for everyone else. The percent of our sample claiming at age 67 or later is 18 percent. 
Table 1 also presents mean annual earnings by age, expressed in 2010 dollars and top-coded at $\$ 150,000$ to minimize the effect of outliers. We code those with no Social Security earnings in an year after age 57 as has having zero earnings in that year. Importantly, yearly earnings in the SSA data refer to calendar years, so earnings at a given age are in fact earnings for the year that age was attained (so, in the extreme, calendar year earnings for someone turning 62 in December were primarily earned at age 61). Table 1 shows that at age 57 , those who will claim retirement benefits at 62 have mean annual earnings about 19 percent below those who will claim after 62 (\$36,427 v. $\$ 44,956)$. The slope of the age-earnings profile between ages 57 and 70 is also markedly different for age62 claimants compared to later claimants. Mean annual earnings of age-62 claimants decline by an order of magnitude between ages 57 and 63 (from $\$ 36,427$ to $\$ 3,127$ ), with the sharpest drops occurring between ages 61 and 62, and 62 and 63, thus coinciding with benefit claiming. From age 63 on, the downward trajectory flattens. Among later claimants, mean annual earnings decline by much less between ages 57 and 62 (from $\$ 44,956$ to $\$ 36,420$ ), but after age 62 mean earnings drop sharply each year until age 66 , after which the rate of decline attenuates. By age 70, mean annual earnings in both groups are very low.

\section{Earnings Dynamics and Early Claiming}

Although early and later claimants have similar demographic characteristics, their age-earnings profiles are substantially different. In this section, we explore graphically these earnings dynamics and their interaction with the age of benefit initiation. 
We begin in Figure 3 by sub-setting our sample by age of first benefit receipt and then plotting the age-earnings profile for each group. Recall that earnings refer to annual earnings in the year of age attainment, so, for instance, earnings in the year of reaching age 62 reflect a mix of earnings received at ages 61 and 62 . The first notable feature of the ageearnings profiles is the relative ordering of their intercepts at age 57. Those claiming at 62 have the lowest earnings at age 57; those claiming at 63 have somewhat higher earnings at 57; those claiming at 64 have higher earnings still, and so forth. This pattern indicates a strong positive correlation between age-57 earnings and subsequent claiming age, though the pattern is reversed after age 66.

A second important feature common to all age-earnings profiles is their downward trajectory. Mean annual earnings decline after age 57 for all groups, regardless of claiming age, reflecting a combination of reductions at the intensive and extensive margins. Although mean annual earnings decline for all groups, the rate of decline during the late 50 's and early 60 's is steepest for the earliest claimants, with slopes that become systematically less steep for later claimants.

The third and most striking element of Figure 3 is that all age-earnings profiles decline precipitously in the year of claiming and the year thereafter. The two-year adjustment reflects the timing of our earnings measures, which give earnings in the year the individual reaches a given age. Consider people who initiate a claim for retirement benefits at some age. On average this will occur about half-way through the calendar year they reach that age. If claimants reduce their earnings as soon as they file for benefits, about one-half of the cut will be measured in the year they reach the claiming age. 
The three groups who claim prior to their FRA (at ages 62,63, or 64) all show a very distinctive pattern of very low earnings once they start to receive retirement benefits. By age 67 , for example, average earnings of people who claim at 62 are $\$ 2300$, average earnings of people who claim at 63 are $\$ 3500$, and average earnings of people who claim at 64 are $\$ 3800$. In contrast, people who initiate a claim at age 65 have average earnings of $\$ 17,300$ at age 67 . Early claimers as a group seem to be fundamentally different from those who retire on or after their FRA.

Taken as a whole, the earnings profiles in Figure 3 exhibit a pronounced pattern of kinks that are closely associated with the initiation of retirement benefits and point to a causal link between claim initiation and earnings - particularly for the early claimers. One aspect of our data structure that may cloud this interpretation is that we observe only the oldest cohorts (b. 1934-1939) through age 70. Thus the cohort composition of a given claimant age group is changing with age. Moreover, the cohorts in our analysis were differentially impacted by policy changes, such as the increase in the FRA, which commenced with the 1938 cohort; the increase in the delayed retirement credit (increasing by one-half a percentage point every two years for the 1934-1942 cohorts), and the repeal of the earnings test for people above their FRA, which primarily affected the 1939 and later cohorts, who had not yet reached age 62 at the time of the repeal in 2000 .

To address these issues, we show in Figure 4 the age-earnings profiles for the 19341937 birth cohorts only. These four cohorts are observed continuously from age 57 (in 1991) through age 70 (in 2009). They have the same FRA of 65, they had already turned 62 when the repeal of the earnings test above the FRA was announced, and although the delayed retirement credit rose from $5.5 \%$ to $6.5 \%$ across the four cohorts, the credit was 
still less than actuarially fair, and so all four cohorts faced a modest disincentive to delay claiming beyond their FRA. Figure 4 shows that adjusting for these compositional and policy environment differences does not materially alter the differences in the earnings profiles by claiming age. Mean earnings at 57 increase with claiming age as before, all trajectories decline but at a decreasing rate as claiming age rises, and all of the profiles display the kink at claiming age and reverse kink two years later. One slight exception to this general pattern is the group claiming at 65; their earnings decline at a steeper rate during their late 50s and early 60s compared to age-64 claimants. This is likely driven by the fact that included among the age- 65 claimants are people who initiated SSDI payments after age 58 and who were automatically converted to regular Social Security retirement benefits at 65 . Since eligibility for SSDI benefits is conditional on having low earnings (due to disability), the inclusion of these individuals among the age- 65 claimants would tend to lower mean earnings for this group.

These general patterns are not, however, driven by the presence of low earners in each claiming group. To see this we next subset our sample by quartile of prior earnings, where prior earnings are measured as average earnings from ages 53-57. Table 2 presents sample characteristics by prior earnings. As expected, there are large differences in demographic characteristics by prior earnings quartile, with the percent male and percent White, non-Hispanic rising with earnings. The second panel of Table 2 summarizes the earnings dynamics occurring between age 57 and age 61 , just prior to first eligibility for Social Security retirement benefits. First, there is substantial persistence in earnings in the years prior to benefit eligibility, with about 42 percent of people in the first three quartiles persisting in the same (conditional) quartile at age 61, and about 52 percent of people in 
quartile 4 persisting in the upper quartile at age $61 .^{10}$ In general, more people transition to a lower conditional earnings quartile or to zero earnings over the pre-eligibility years than transition to a higher quartile. Fully 33 percent of people in the first quartile of prior earnings have no earnings at age 61 . While substantially fewer in the higher quartiles transition to zero earnings, the percent with no earnings at age 61 is relatively high for these groups as well-ranging from 18-20 percent. Among those in the higher quartiles (24), a substantial fraction transition to a lower conditional earnings quartile by age 61 ; this reflects both intensive margin changes in hours worked and also any wage reductions associated with job changes (perhaps due to partial retirement).

The next panel of Table 2 shows mean real earnings by age for each prior earnings quartile. These data are also presented graphically in Figure 5. Perhaps most striking of all is how the earnings profiles for all groups—and especially the highest earners—exhibit sharp slope changes at age 62, becoming steeper for about two years before flattening out. The result is a remarkable convergence in earnings across prior earnings quartiles by the time individuals are in their mid-60's.

The bottom panel of Table 2 shows how the percent initiating benefits by age varies across earnings quartiles. A surprising fact is that there are only modest differences in the percent claiming at each age across the earnings quartiles. For example, while 36.5 percent of people in the first quartile of prior earnings claim at age 62 , so do 28.6 percent of those in the fourth quartile of prio earnings. Claiming at 63 or 64 is relatively uncommon across

\footnotetext{
${ }^{10}$ For earnings after age 57, we use extended earnings quartiles, which take on values of zero for those with 0 earnings, and 1-4 for individuals with earnings in the first through fourth conditional quartiles of earnings. Note there is no extended quartile for prior earnings as measured here, since our sample definition requires everyone to have positive earnings at age 57.
} 
the groups, and another 36-37 percent claim at either age 65 or 66. Delayed claiming at age 67 or later is somewhat more common among those in the upper quartiles.

To complete our analysis of earnings dynamics and benefit claiming we show in Figure 6 how earnings evolve differentially across groups defined by the interaction of prior earnings quartile and age of benefit initiation (where for readability we distinguish only claiming at 62 and after 62 ). Among the highest earners - those with prior earnings in the fourth quartile (Q4) —-we note the same pronounced differences between those who claim at 62 and those who claim after 62 as we showed for all earnings groups combined (see Figure 4). The earnings of age-62 claimants plummet linearly from a Q4 mean of $\$ 78,490$ at age 57 to (nearly) zero by age 63 , and remain at that level through age 70 . Among high earners who claim after 62, the decline in earnings from 57 to 62 is less steep, but even so mean earnings begin to fall precipitously after age 62 , presumably coincident with claiming. This basic pattern is present for all four quartiles o prior earnings. The uniformity of the pattern is surprising since a priori we would have expected to find the most pronounced effects of claiming on labor supply among those in the second quartile of earnings - the group most affected by the substitution and income effects created by the retirement earnings test.

One way to understand the magnitude of our findings is to compute the foregone earnings associated with early benefit claiming. We first compute the sum of earnings from age 62 to 70 for each individual, and then regress that on a series of indicators for benefit initiation at 62,63 and 64 . We include only the $1935-37$ birth cohorts, so the reference group is those who start benefits at 65 , the FRA for these cohorts. We estimate the model separately by prior earnings quartile, and with and without controls. The controls include 
annual earnings from age 57 to age 61 (five variables), indicators for race, gender, and year of birth. The regression estimates are shown in Table 3.

If we assume the demographic and detailed earnings controls absorb unobserved aspects of labor supply and the cumulative effect of demand shocks, then the coefficients in columns (2), (4), (6), and (8 measure the effect of early claiming on cumulative earnings from age 62-70. Among those in the first quartile of prior earnings, claiming at 62 leads to a $\$ 42,206$ reduction in cumulative earnings through age 70 . Compared to mean cumulative earnings for those who start benefits at $65(\$ 103,924)$, this represents a reduction of 41 percent. The effect of claiming at 63 is similar, while the effect of claiming at 64 is a bit lower $(-\$ 34,752)$. Among those in the second quartile of prior earnings, claiming at 62 leads to a loss in cumulative earnings of $\$ 75,606$ or 53 percent compared to mean cumulative earnings for those in Q2 who start benefits at $65(\$ 143,092)$. The effect for those in Q3 is $-\$ 131,437$, representing a loss of 62 percent relative to claiming at 65. Finally, the effect of early claiming at 62 on cumulative earnings from 62 to 70 for people in the top earnings quartile is $-\$ 263,215$ or 59 percent.

By any measure these are large effects. Our estimates of the foregone earnings from early claiming imply a significant fraction of people could make a material difference in their standard of living if they recaptured even a portion of these potential earnings and allocated them to current or future consumption. An important question, however, is whether people claim early because of very strong preferences for leisure, or because they face limited labor market opportunities. A related question is why do they not return to work after they pass FRA, when the retirement earnings test no longer applies? We turn to the role of labor market conditions next. 


\section{The Effect of Economic Conditions on Early Claiming}

One explanation for high rates of early benefit claiming in the presence of a large actuarial reduction in benefits and a large implicit tax on earnings through the earnings test is that early claimants have poor labor market opportunities (perhaps as a result of labor demand shocks) and therefore the opportunity cost of claiming is small. Indeed, the declining earnings profiles shown in earlier figures could be the cumulative result of labor market shocks that systematically reduce opportunities for older workers. That said, the models in Table 3 suggest that the opportunity cost of claiming early, measured in terms of foregone earnings, is anything but small, even for those in the lowest earnings quartile. In this section we examine the economic forces that lead to early claiming in order to assess the degree to which economic shocks drive early claiming (and the persistence of low earnings following claiming).

In Table 4 we present a series of reduced form models for benefit initiation at 62 (compared to after 62) as a function of the change in labor demand conditions experienced from age 57 to 62 in the individual's state of residence as of age 57 . We model the change in labor demand as the log of the annual change in aggregate state employment (from the QCEW). Column (1) shows the estimated effect of the change in state employment between ages 61 and 62, controlling for state and year effects, and fo dummies for quartiles of prior earnings (average earnings from ages 53-57). The estimates imply that a ten percent decline in state employment between ages 61 and 62 leads to a statistically significant increase in the probability of claiming at 62 of 0.067 , an increase of about 22 percent (from a base of 0.306). In column (2), we add the sequence of annual state employment changes 
since age 57. The effect of a 10 percent decline in state employment between 61 and 62 on claiming at 62 is somewhat smaller (0.055), but the changes in employment prior to 61 are not individually statistically significant. In column (3), we use instead the cumulative change in state employment from age 57 to 61 . The cumulative change is statistically significant and implies a ten percent decrease in cumulative state employment between 57 and 61 leads to a 0.021 increase in the likelihood of claiming at age 62 .

Columns (4)-(6) repeat this analysis but also include indicator variables for the interaction of extended quartiles of earnings at age 60 and 61 (i.e., 24 dummy variables). These are included to control for the dynamics of earnings in the period prior to first benefit eligibility. Column (6) shows the result of these extensive controls-the effect of the cumulative change in state employment between 57 and 61 diminishes, becoming insignificant. This implies that the detailed earnings controls are sufficient to absorb the cumulative impact of labor demand shocks on benefit claiming, and also lends support to our interpretation of the estimates in Table 3 as representing the effect of early claiming on foregone earnings.

Table 5 presents two extensions of the estimation results in Table 4. First, we show estimates of models for the probability of initiating benefits at age 62 , fit separately by earnings quartile based on average earnings from ages 53 to 57 . Second, we present a parallel set of models for the probability of initiating benefits at age 62,63 , or 64 . The latter are useful in helping to assess whether the primary effect of labor market shocks is to shift people to claiming as early as possible instead of a year or two later (but still prior to the FRA), or whether labor market shocks are strong enough to push people between claiming at their FRA and as early as possible. In both cases we focus for simplicity on 
specifications that include the change in employment between age 61 and 62, and the cumulative change from age 57 to 61 .

Looking first at the models by earnings quartile group for claiming at age 62 (in the upper panel of the table), notice that effects of labor market shocks appear to be broadly similar across the quartile groups. If anything, however, the effects on the highest earning group are a little larger than for the other groups, suggesting very powerful effects of local labor market conditions on inducing retirement claims even for people with relatively high potential earnings.

Next, looking at the models for claiming at age 62-64, notice that the point estimates of the effects of labor market shocks are a little smaller than the effects on claiming at age 62 , suggesting that about one-half of the measured impact on claiming at age 62 arises from a substitution between earliest possible claiming (at age 62) and slightly delayed but still early claiming at ages 63 and 64, while the other half arises from a shift to claiming at age 62 from claiming at age 65 or later. An interesting exception to this general pattern is the relatively large coefficient of the age 61-62 employment shock on the claiming rate at ages 62-64 of the fourth quartile group (in column 5 of the table). The -0.63 effect is about $80 \%$ of the magnitude of the corresponding -0.76 effect on claiming at age 62 , implying that among higher-wage individuals local labor market shocks at age 62 induce people to either claim early, or wait to their FRA. Given the very large impacts of claiming early on total earnings between age 62 and 70 for this group noted in Table 3, this is an economically important shift.

Overall, the results in Tables 4 and 5 suggest that labor demand shocks are an important determinant of early claiming behavior. To quantify the general impact of 
demand side factors, consider the 4.5 percentage point decline in the national employmentpopulation rate in the US from 2008 to 2010 . The models in Table 4 suggest that this fall might have been expected to cause a roughly 3 percentage point rise in the fraction of people who initiate Social Security retirement benefits at age 62 which is in fact very close to the actual rise observed in this time interval.

\section{Discussion and Conclusion}

We have used individual Social Security earnings and benefit claim records for cohorts born between 1934 and 1947, merged with information on state-wide employment changes, to measure the effect of local labor market shocks on the decision of when to initiate Social Security retirement benefits, and quantify the effects of different initiation choices on earnings from age 62 to 70 . A simple graphical analysis shows that the earnings profiles of benefit initiators are closely tied to their initiation date, particularly for people who start receiving benefits before their full retirement age. Within a year of initiating retirement benefits, early claimants have reduced their earnings to an average of just a few thousand dollars per year. This is true even for early claimants who, in their mid-50s, were in the top quarter of earners.

The earnings profiles of the earliest claim initiators also reveal a pattern of systematic declines in the years prior to reaching age 62 , which suggests that early claiming is in part an endogenous response to negative earnings shocks. We confirm this by looking directly at how labor market shocks between the ages of 58 and 62 affect the probability of starting retirement benefits at age 62 , or age ages $62-64$. We find a relatively large effect of local shocks on the rate of benefit initiation at age 62 - large enough to fully 
explain the recent rise in claim rates at ages 62 as a consequence of the collapse of labor demand during the early years of the Great Recession. Importantly, labor market shocks affect the claim behavior of all earnings groups, not just the lowest earners.

A key question raised by our findings is whether the low post-claim earnings of early benefit claimants are due in part to the dynamic incentive effects of the earnings test (and other features of the Social Security benefit system), or to heterogeneity in the tastes and opportunities of individuals who claim benefits before their full retirement age. A decisive answer to this question is a top priority for future research. 


\section{References}

Autor, David, Nicole Maestas, Kathleen Mullen and Alexander Strand. 2014. "Does Delay Cause Decay? The Effect of Administrative Decision Time on the Labor Force Participation and Earnings of Disability Applicants." MRRC Working Paper \#2011258, September 2011; revised December 2014.

Autor, David and Mark Duggan. 2003. The Rise in the Disability Rolls and the Decline in Unemployment. The Quarterly Journal of Economics 118(1): 157-205.

Black, Dan, Daniel Kermit and Seth Sanders. 2002. The Impact of Economic Conditions on Participation in Disability Programs: Evidence from the Coal Bust and Boom. The American Economic Review 92(1):27-50.

Coile, Courtney C. and Philip B. Levine. 2007. "Labor Market Shocks and Retirement: Do Government Programs Matter?” Journal of Public Economics, 91, 1902-1919.

Davis, Steven and Till von Wachter. 2011. "Recessions and the Cost of Job Loss." Brookings Papers on Economic Activity, 43, 1-72.

Friedberg, L. 2000. The labor supply effects of the social security earnings test. Review of Economics and Statistics, 82(1), 48-63.

Friedberg, Leora, and Anthony Webb. 2009. "New Evidence on the Labor Supply Effects of the Social Security Earnings Test. Chapter 23 in Tax Policy and the Economy, edited by Jeffrey R. Brown and James M. Poterba. Published by the National Bureau of Economic Research."

Gruber, Jonathan and Peter Orszag. 2003. "Does The Social Security Earnings Test Affect Labor Supply And Benefits Receipt?” National Tax Journal, Vol. 56, No. 4, pp. 755773.

Maestas, Nicole, Kathleen Mullen and Alexander Strand. 2013. "Does Disability Insurance Receipt Discourage Work? Using Examiner Assignment to Estimate Causal Effects of SSDI Receipt.” American Economic Review, 103(5): 1797-1829.

Jacobson, Louis, Robert LaLonde and Daniel Sullivan. 1993. “Earnings Losses of Displaced Workers." American Economic Review, Vol. 83, No. 4, pp. 685-709.

Olsen, Anya, and Russell Hudson. 2009. Social Security Administration's Master Earning File: Background Information. Social Security Bulletin, 69(3), 29-46.

Panis, Constantijn, Roald Euller, Cynthia Grant, Melissa Bradley, Christine E. Peterson, Randall Hirscher, and Paul Steinberg. 2000. SSA Program Data User's Manual. Baltimore, MD: Social Security Administration.

Social Security Administration. 2013. Annual Statistical Supplement to the Social Security Bulletin. Baltimore, MD: Social Security Administration. Accessed on October 13 2014 at http://www.ssa.gov/policy/docs/statcomps/supplement/2013/6b.html. 
Song, J. G., \& Manchester, J. 2007. New evidence on earnings and benefit claims followin changes in the retirement earnings test in 2000. Journal of Public Economics, 91(3) 669-700.

Von Wachter, T., Song J., \& Manchester, J. 2009. “Long-term Earnings Losses Due to MassLayoffs During the 1982 Recession: An Analysis Using Longitudinal Administrative Data from 1974 to 2004. Unpublished Manuscript.

Yagin, Daniel. 2014. “Moving to Opportunity? Migratory Insurance over the Great Recession." Unpublished Manuscript. 
Figure 1: Fraction Initiating Social Security Benefits at Age 62, and Unemployment Rate at Age 62, by Year of Birth

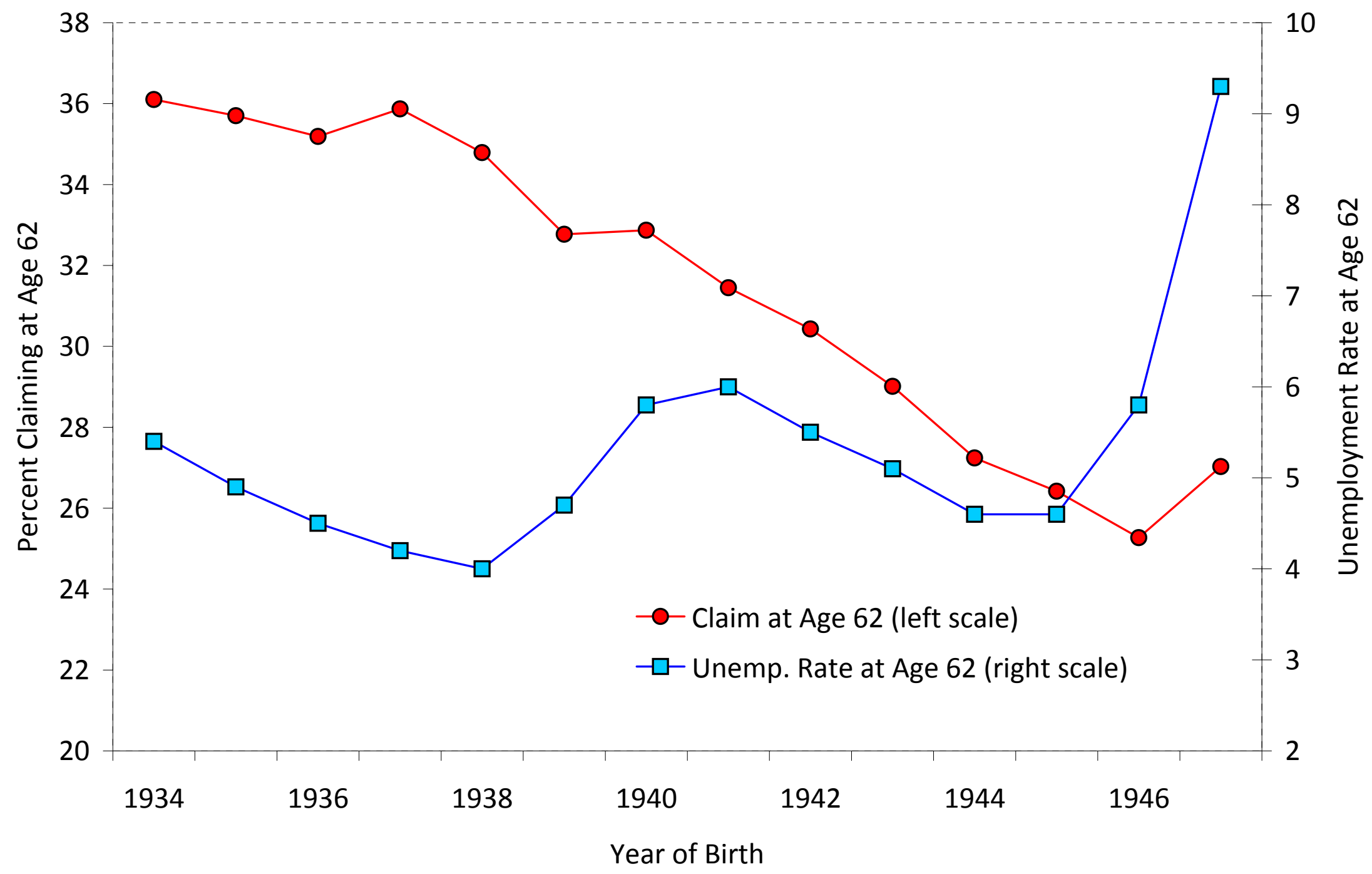


Figure 2: Fractions Initiating Social Security Claims at Different Ages, By Birth Cohort

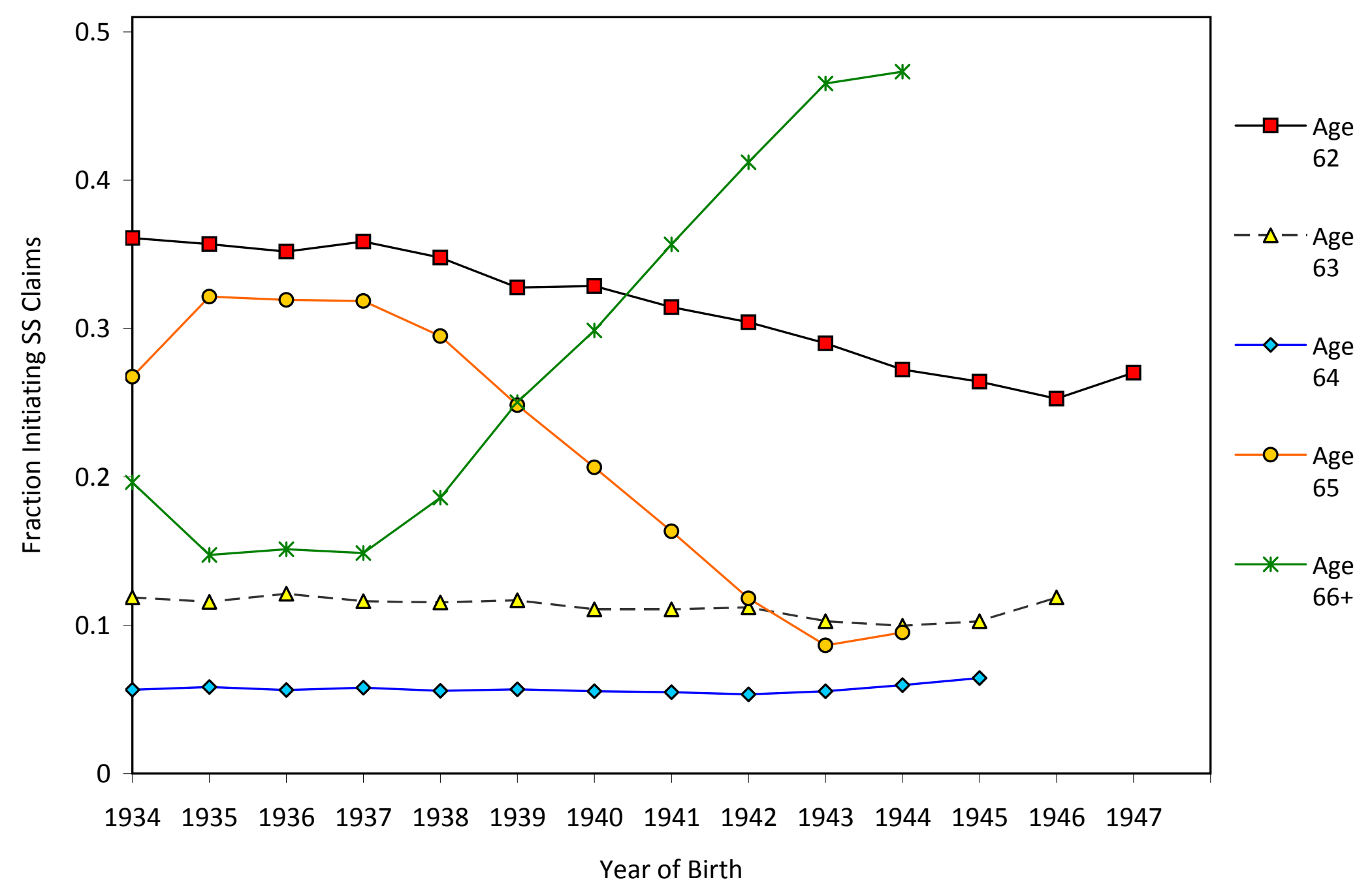


Figure 3: Earnings At Ages 57 to 70 By Age of Initiation of Social Security Retirement Benefits

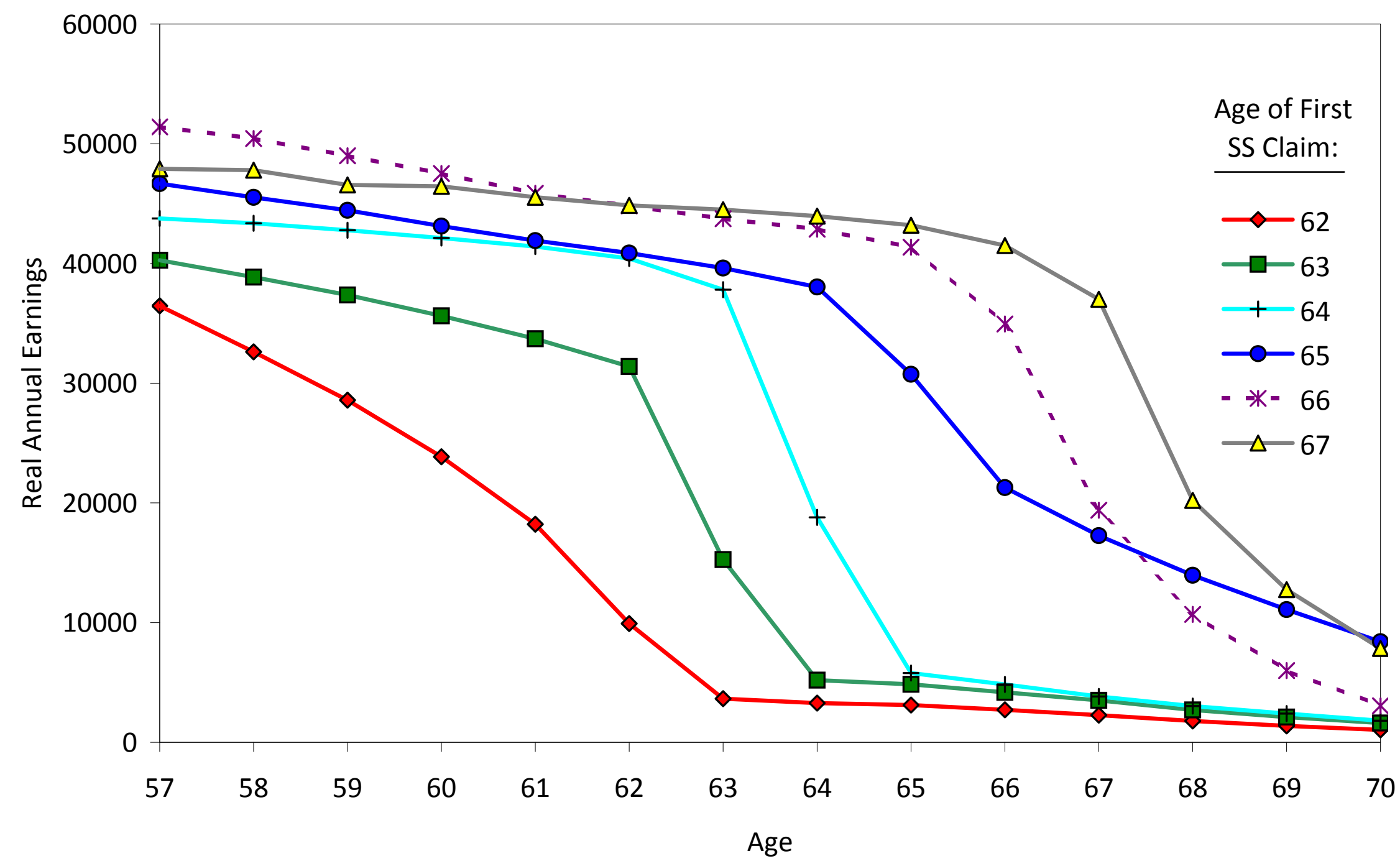


Figure 4: Earnings At Ages 57-70 By Age of Initiation of Social Security Retiremement Benefits: 1934-1937 Birth Cohorts Only

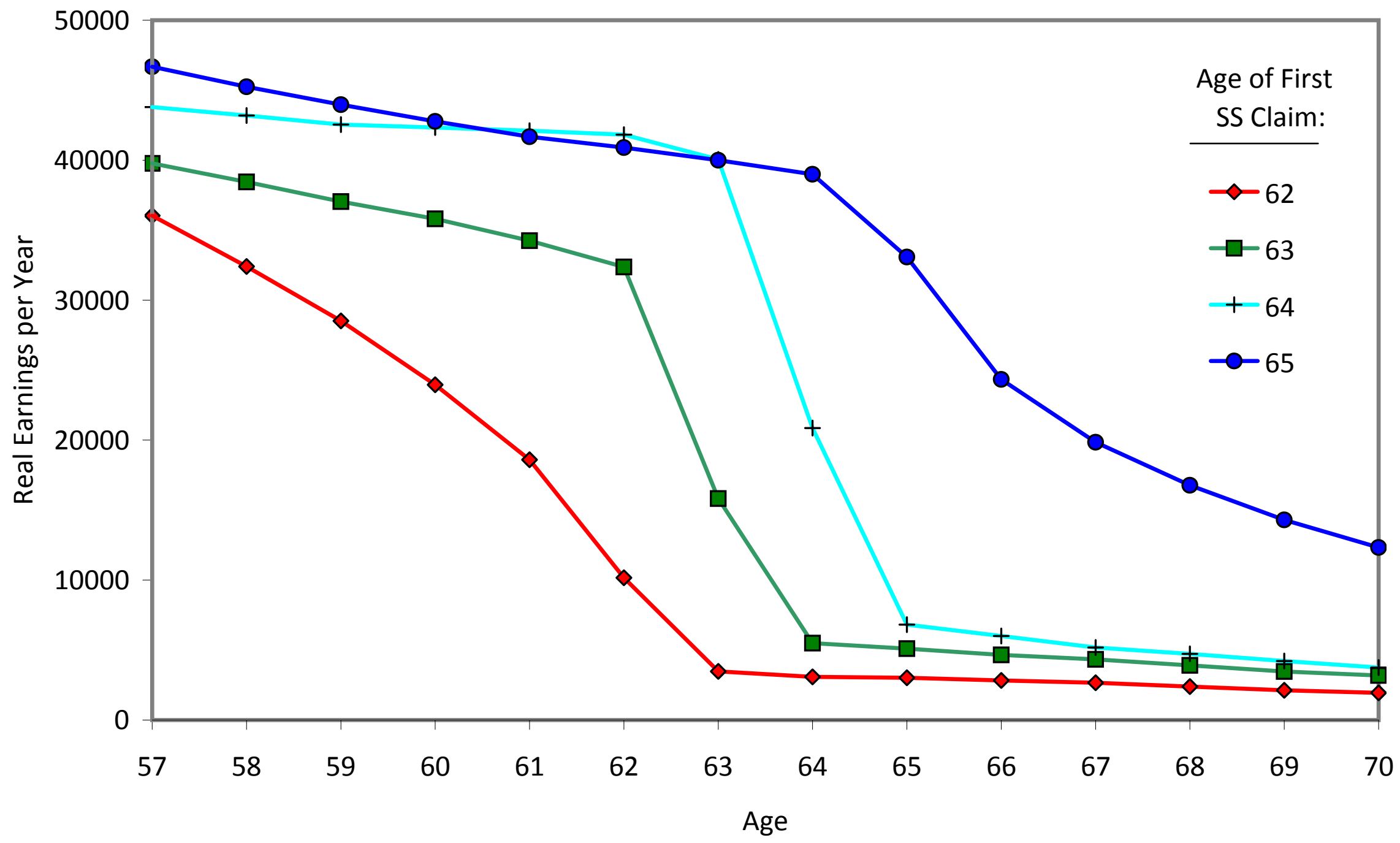


Figure 5: Earnings at Ages 57-70 By Quartile of Age 53-57 Earnings

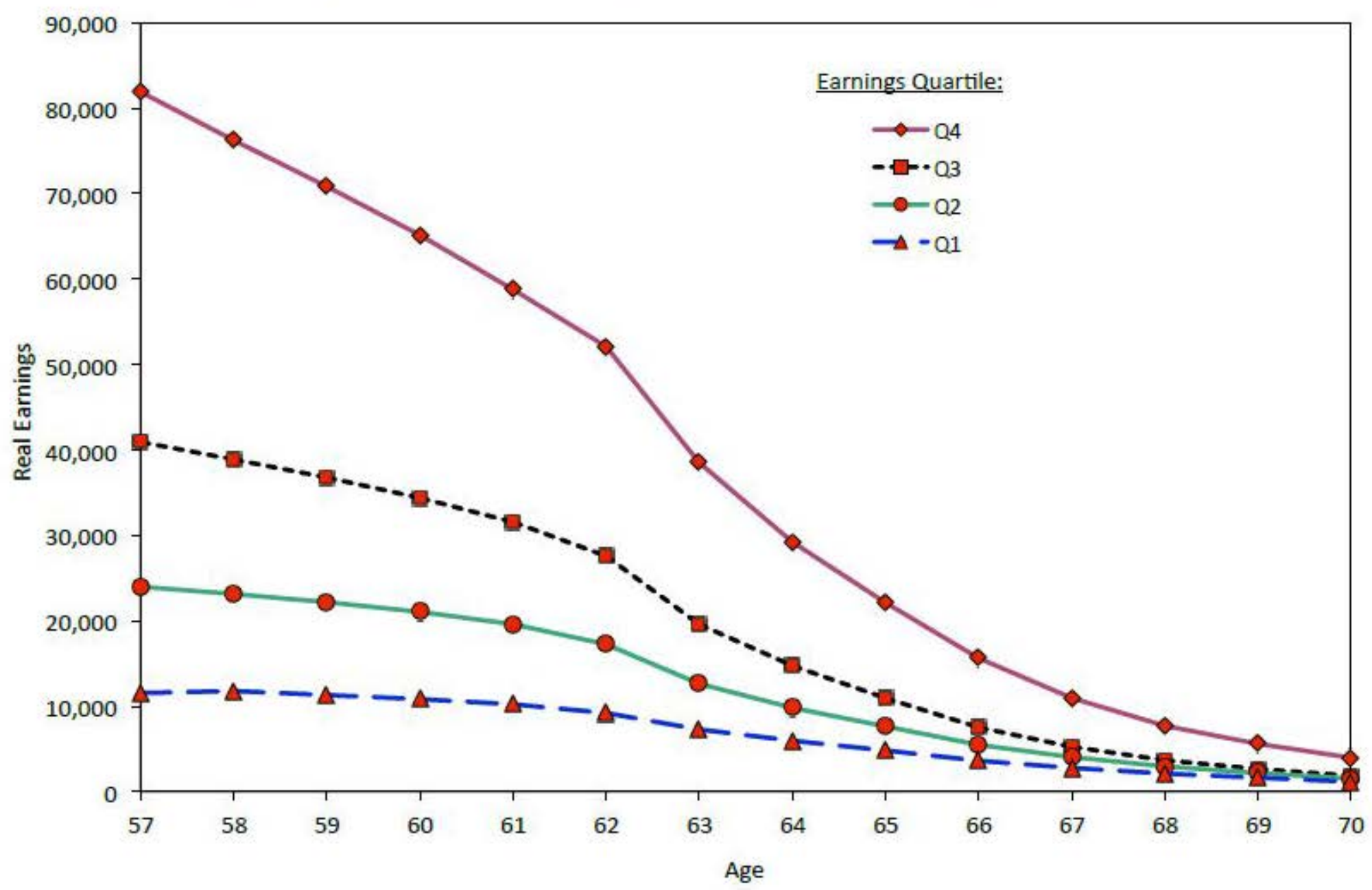


Figure 6: Earnings at Ages 57-70 By Quartile of Age 53-57 Earnings and Age of Initiation of Soc. Security Retirement Benefits

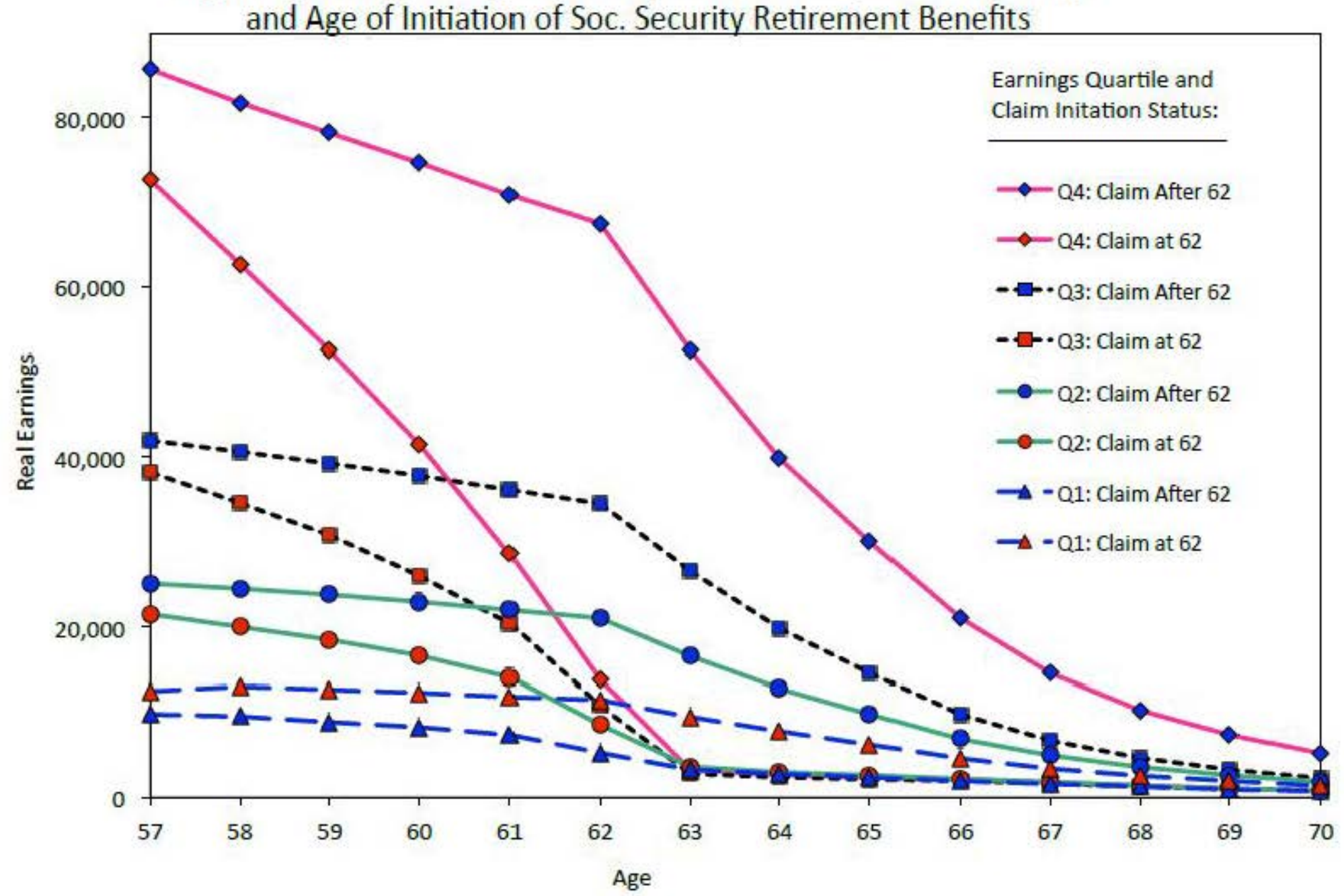


Table 1: Characteristics of Analysis Sample, By Early Claiming Status

\begin{tabular}{|c|c|c|c|}
\hline & $\begin{array}{l}\text { All } \\
\text { (1) }\end{array}$ & $\begin{array}{l}\text { Claim at } \\
\text { Age } 62 \\
(2)\end{array}$ & $\begin{array}{l}\text { Claim After } \\
\text { Age } 62 \\
\text { (3) }\end{array}$ \\
\hline Percent Male & 52.5 & 52.7 & 52.4 \\
\hline Percent White non-Hispanic & 83.6 & 85.9 & 82.6 \\
\hline Percent Black non-Hispanic & 9.3 & 9.2 & 9.3 \\
\hline Percent Hispanic & 1.2 & 0.6 & 1.4 \\
\hline Percent with Missing State & 1.1 & 1.6 & 0.9 \\
\hline \multicolumn{4}{|c|}{ Age at Initiation of Retirement Benefit Claim } \\
\hline Percent at 62 & 30.8 & 100.0 & -- \\
\hline Percent at 63 & 10.0 & -- & 14.4 \\
\hline Percent at 64 & 4.6 & -- & 6.6 \\
\hline Percent at 65 & 15.2 & -- & 21.9 \\
\hline Percent at 66 & 21.5 & -- & 31.0 \\
\hline Percent at 67 or later & 18.0 & -- & 26.0 \\
\hline \multicolumn{4}{|c|}{ Mean Annual Earnings by Age (2010 dollars) } \\
\hline Age 57 & 42,333 & 36,427 & 44,956 \\
\hline Age 58 & 40,029 & 32,452 & 43,394 \\
\hline Age 59 & 37,616 & 28,328 & 41,742 \\
\hline Age 60 & 34,977 & 23,604 & 40,028 \\
\hline Age 61 & 31,945 & 17,946 & 38,162 \\
\hline Age 62 & 28,221 & 9,762 & 36,420 \\
\hline Age 63 & 20,698 & 3,254 & 28,446 \\
\hline Age 64 & 15,804 & 2,705 & 21,622 \\
\hline Age 65 & 12,027 & 2,382 & 16,311 \\
\hline Age 66 & 8,492 & 2,071 & 11,344 \\
\hline Age 67 & 6,020 & 1,733 & 7,924 \\
\hline Age 68 & 4,308 & 1,365 & 5,615 \\
\hline Age 69 & 3,127 & 1,050 & 4,050 \\
\hline Age 70 & 2,207 & 791 & 2,835 \\
\hline Number of Observations & 227,148 & 69,861 & 157,287 \\
\hline \multicolumn{4}{|c|}{$\begin{array}{l}\text { Notes: sample includes people born between } 1934 \text { and } 1947 \text { (inclusive) who had positive Social } \\
\text { Security earnings at age 57, did not initiate a DI claim prior to age } 58 \text {. State is obtained from } \\
\text { information on employer at age } 57 \text {. Earnings are censored at 150,000 (in } 2010 \text { dollars). }\end{array}$} \\
\hline \multicolumn{4}{|c|}{$\begin{array}{l}\text { Observations with no Social Security earnings are set to } 0 \text { earnings. All individuals are observed to } \\
\text { at least age } 62 \text {. Later cohorts are only observed to } 2009 \text {. Mean earnings by age for ages } 63+\text { are for } \\
\text { people who reach that age on or before } 2009 \text {. }\end{array}$} \\
\hline
\end{tabular}


Table 2: Characteristics of Individuals by Quartile of Average Earnings, Age 53-57

\begin{tabular}{|c|c|c|c|c|c|}
\hline & \multirow[b]{2}{*}{$\begin{array}{l}\text { All } \\
(1) \\
\end{array}$} & \multicolumn{4}{|c|}{ Quartile of Average Earnings, Age 53-57 } \\
\hline & & $\begin{array}{l}\text { st } \\
(2)\end{array}$ & $\begin{array}{l}\text { 2nd } \\
\text { (3) }\end{array}$ & $\begin{array}{l}3 r d \\
(4)\end{array}$ & $\begin{array}{l}\text { 4th } \\
\text { (5) }\end{array}$ \\
\hline Male (\%) & 52.5 & 33.5 & 36.9 & 53.8 & 78.7 \\
\hline White Non-Hispanic & 83.6 & 78.6 & 81.3 & 84.8 & 87.9 \\
\hline Black Non-Hispanic & 9.3 & 9.6 & 11.3 & 9.9 & 6.4 \\
\hline Hispanic & 1.2 & 3.6 & 1.4 & 0.3 & 0.1 \\
\hline \multicolumn{6}{|c|}{ Earnings Quartile At Age 61: } \\
\hline No earnings & 21.4 & 33.2 & 19.9 & 18.2 & 18.0 \\
\hline 1st quartile & 19.9 & 41.4 & 19.8 & 12.8 & 12.3 \\
\hline 2nd quartile & 20.6 & 19.5 & 42.7 & 15.3 & 6.1 \\
\hline 3rd quartile & 19.6 & 4.5 & 15.8 & 41.8 & 11.8 \\
\hline 4th quartile & 18.4 & 1.3 & 1.8 & 12.0 & 51.9 \\
\hline \multicolumn{6}{|l|}{ Real Earnings by Age: } \\
\hline Ages 53-57 (average) & 42,333 & 11,515 & 23,999 & 40,910 & 81,952 \\
\hline Age 58 & 40,030 & 11,749 & 23,129 & 38,906 & 76,279 \\
\hline Age 59 & 37,617 & 11,296 & 22,178 & 36,787 & 70,874 \\
\hline Age 60 & 34,977 & 10,814 & 21,008 & 34,382 & 65,155 \\
\hline Age 61 & 31,945 & 10,201 & 19,573 & 31,556 & 58,775 \\
\hline Age 62 & 28,221 & 9,210 & 17,233 & 27,572 & 52,137 \\
\hline Age 63 & 20,698 & 7,246 & 12,609 & 19,613 & 38,523 \\
\hline Age 64 & 15,804 & 5,966 & 9,789 & 14,697 & 29,237 \\
\hline Age 65 & 12,027 & 4,812 & 7,601 & 10,954 & 22,146 \\
\hline Age 66 & 8,492 & 3,628 & 5,473 & 7,504 & 15,604 \\
\hline Age 67 & 6,020 & 2,765 & 4,003 & 5,222 & 10,910 \\
\hline Age 68 & 4,308 & 2,113 & 2,924 & 3,680 & 7,714 \\
\hline Age 69 & 3,127 & 1,600 & 2,168 & 2,624 & 5,559 \\
\hline Age 70 & 2,207 & 1,144 & 1,517 & 1,838 & 3,937 \\
\hline \multicolumn{6}{|c|}{ Percent Initiating Social Security Retirement Benefits at Age: } \\
\hline Age 62 & 30.8 & 36.4 & 30.5 & 29.3 & 28.6 \\
\hline Age 63 & 10.0 & 9.2 & 10.7 & 10.7 & 9.2 \\
\hline Age 64 & 4.6 & 3.9 & 4.7 & 5.1 & 4.4 \\
\hline Age 65 & 15.2 & 11.9 & 15.5 & 16.0 & 16.4 \\
\hline Age 66 & 21.5 & 25.2 & 21.4 & 19.9 & 20.5 \\
\hline Age $67+$ or censored & 18.0 & 13.5 & 17.2 & 19.1 & 20.8 \\
\hline
\end{tabular}

Note: see notes to Table 1. 
Table 3: Estimates of Effect of Early Retirement Benefit Claiming on Cumulative Earnings, Age 62-70, 1935-37 Birth Cohorts Only

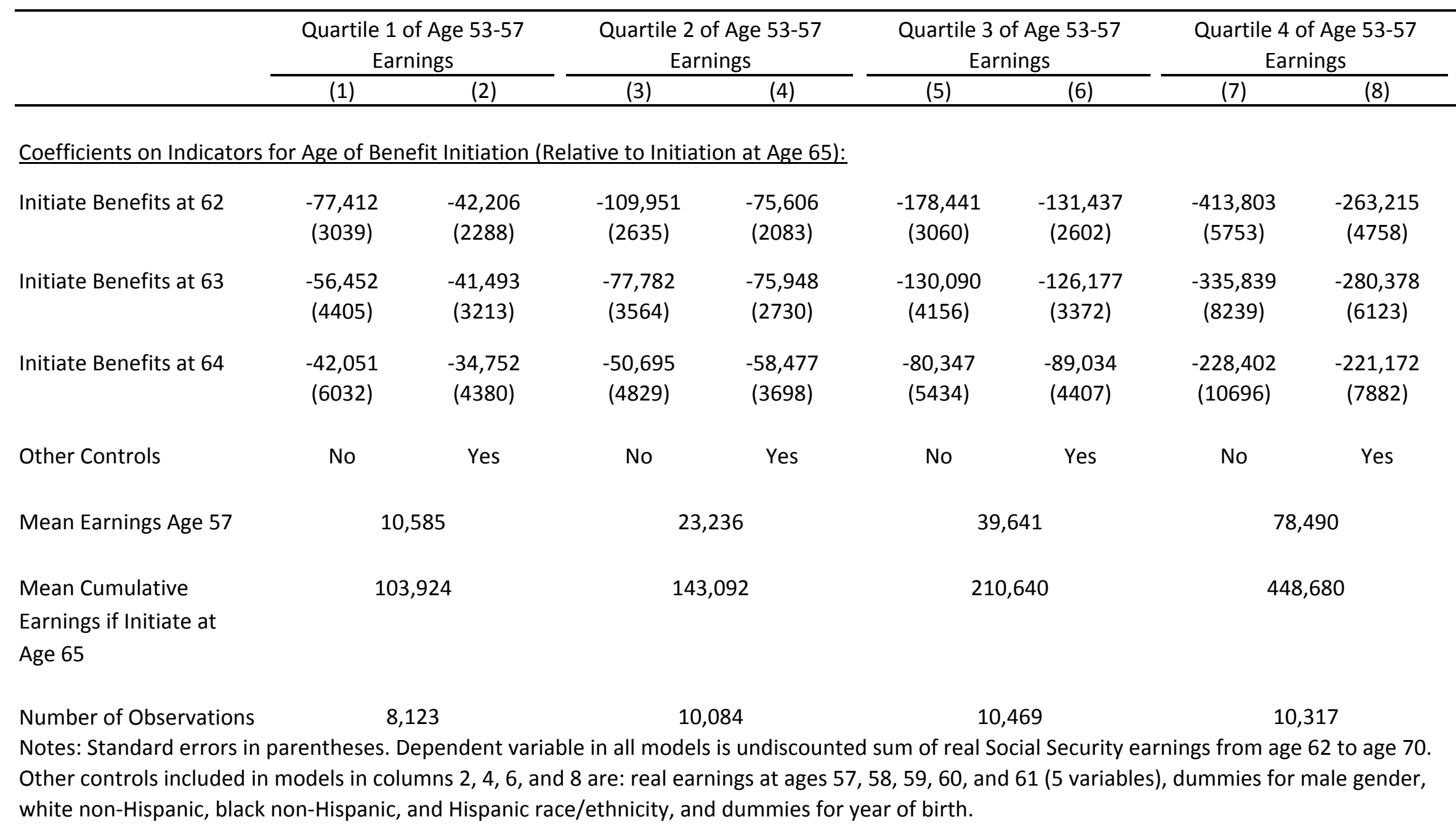


Table 4: Linear Probability Models for Initiation of Social Security Retirement Benefits at Age 62

\begin{tabular}{|c|c|c|c|c|c|c|}
\hline & \multicolumn{6}{|c|}{ Dependent Variable = Indicator for Initiating Soc. Security Retirement Benefits at Age 62} \\
\hline & $(1)$ & $(2)$ & (3) & $(4)$ & $(5)$ & (6) \\
\hline \multirow[t]{2}{*}{ Change in State Employment, Age 61 to 62} & -0.67 & -0.55 & -0.57 & -0.60 & -0.49 & -0.55 \\
\hline & $(0.13)$ & $(0.16)$ & $(0.14)$ & $(0.13)$ & $(0.16)$ & $(0.13)$ \\
\hline \multirow[t]{2}{*}{ Change in State Employment, Age 60 to 61} & & -0.24 & & & -0.20 & \\
\hline & & $(0.20)$ & & & $(0.19)$ & \\
\hline \multirow[t]{2}{*}{ Change in State Employment, Age 59 to 60} & & -0.20 & & & -0.13 & \\
\hline & & $(0.20)$ & & & $(0.19)$ & \\
\hline \multirow[t]{2}{*}{ Change in State Employment, Age 58 to 59} & & -0.19 & & & 0.05 & \\
\hline & & $(0.20)$ & & & $(0.19)$ & \\
\hline \multirow[t]{2}{*}{ Change in State Employment, Age 57 to 58} & & -0.22 & & & -0.13 & \\
\hline & & $(0.17)$ & & & $(0.17)$ & \\
\hline Cumulative Change in State Employment & & & -0.21 & & & -0.09 \\
\hline Ages 57 to 61 & & & $(0.06)$ & & & $(0.05)$ \\
\hline State Effects (at Age 57), Year Effects & Yes & Yes & Yes & Yes & Yes & Yes \\
\hline Dummies for Quartiles of Earnings & Yes & Yes & Yes & Yes & Yes & Yes \\
\hline \multicolumn{7}{|l|}{ Age 53-57 } \\
\hline Dummies for Extended Quartiles of & No & No & No & Yes & Yes & Yes \\
\hline \multicolumn{7}{|l|}{ Earnings at Age 60 and 61, Interacted } \\
\hline RMSE & 0.5982 & 0.5982 & 0.5982 & 0.5674 & 0.5674 & 0.5674 \\
\hline
\end{tabular}

Notes: Standard errors in parentheses. See Table 1 for description of sample. Dependent variable in all models is indicator for initiating regular Social Security benefits at age 62. Mean of dependent variable is 0.306 . Specifications in columns 4-6 include full interaction of "extended earnings quartiles" at ages 60 and 61 (i.e., 24

dummies). The extended quartile takes on values of 0 for those with 0 earnings, and 1-4 for individuals with earnings in the first-fourth conditional quartiles of earnings. 
Table 5: Linear Probability Models for Initiation of Social Security Retirement Benefits at Age 62 or Ages 62-64

By Quartile of Age 53-57 Earnings:

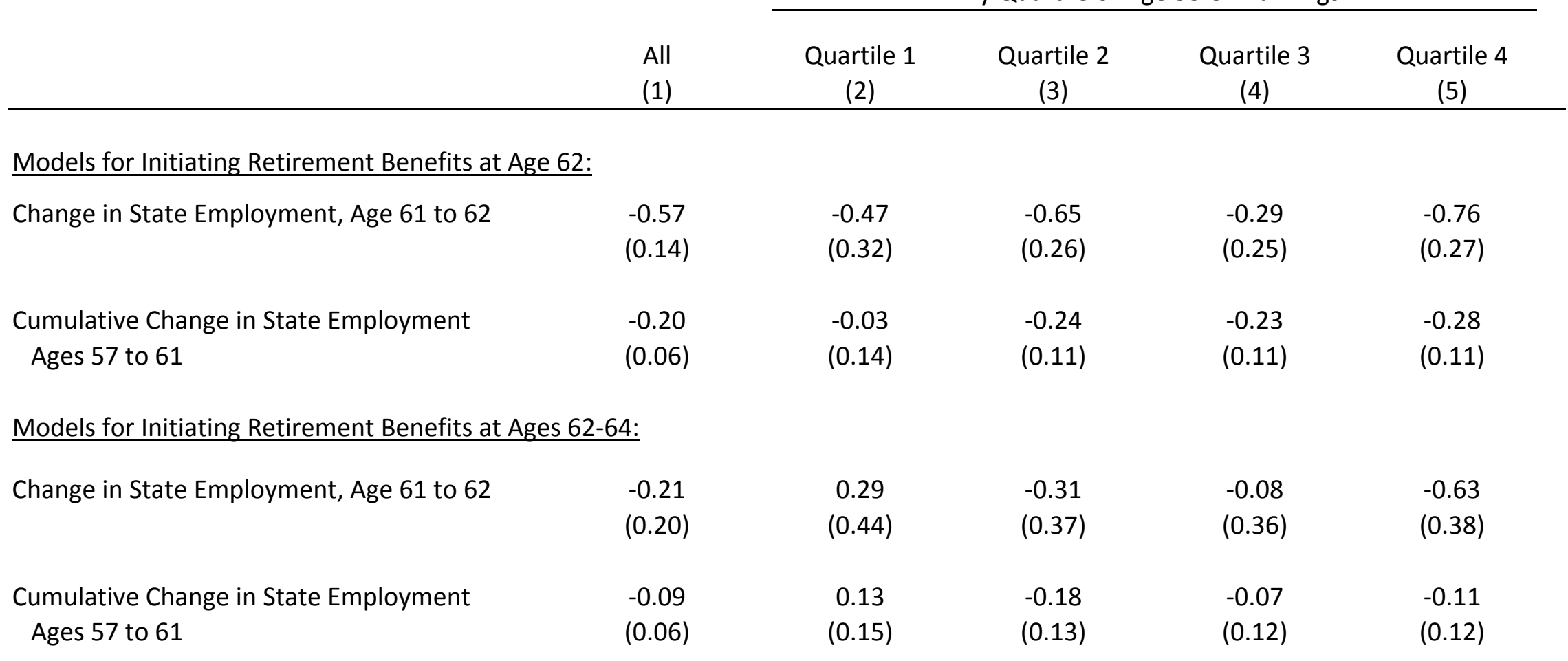

Notes: Standard errors in parentheses. See Table 1 for description of sample. Dependent variable in models in upper panel is indicator for initiating regular Social Security benefits at age 62 (mean=0.306). Dependent variable in models in lower panel is indicator for initiating regular Social Security benefits prior to age 65 (mean=0.541). All models include dummies for year of birth and for state of employment at age 57. 